\title{
EDITORIAL
}

\section{Pleurodesis: what agent should be used?}

Pleurodesis is indicated when one wishes to obliterate the pleural space. The indications for pleurodesis are a symptomatic recurrent pleural effusion or a spontaneous pneumothorax ${ }^{(1)}$. Over the past 70 years many agents have been injected intrapleurally in an attempt to create a pleurodesis. The agents used have included radioisotopes, quinacrine, antineoplastics (nitrogen mustard, bleomycin, mitoxantrone), tetracycline derivatives (tetracycline, doxycycline, minocycline), talc, erythromycin, sodium hydroxide, silver nitrate, iodopovidone, killed Corynebacterium parvum and OK-432 which is an immunostimulant obtained from Streptococcus pyogenes ${ }^{(2)}$.

The mechanism for pleurodesis with most of the agents listed above is thought to be the following: an agent is injected into the pleural space which injures the mesothelial cells lining the pleural space $e^{(2)}$. As a result of the injury, pleural inflammation develops usually in association with a pleural effusion. If the injury is sufficiently severe, the resulting inflammation will lead to the formation of collagen and the visceral and parietal pleura will fuse producing a pleurodesis ${ }^{(2)}$.

In the 1960's and 1970's antineoplastic agents were the most popular agents. Nitrogen mustard was most commonly used and was effective in up to $87 \%$ of patients ${ }^{(3)}$. Originally it was thought that the efficacy of the antineoplastic agents was due to their antitumor effects. However, subsequently it was shown that pleurodesis occurred when the tumor was not controlled and the pleurodesis was attributed to the fibrosing effects of the drugs ${ }^{(2)}$. In recent years, bleomycin has been the antineoplastic agent most commonly used for pleurodesis. This is not due to its greater efficacy, but rather to the fact that the pharmaceutic company who manufactures it completed the necessary paperwork to get it approved by the Federal Drug Administration in the United States. It should be noted that bleomycin does not produce pleurodesis in experimental animals ${ }^{(4)}$. Mitoxantrone is another antineoplastic agent which has been used as a pleurodesing agent. It is not recommended because doses sufficiently high to induce a pleurodesis in animals produce a cardiomyopathy $^{(5)}$. Of all the antineoplastics, nitrogen mustard at a dose of $0.8 \mathrm{mg} / \mathrm{kg}$ is the most effective in producing a pleurodesis in rabbits ${ }^{(6)}$.

When it was realized that it was the fibrosing effects rather than the antineoplastic effects of the agents that was responsible for producing the pleurodesis, non-specific irritants such as talc, tetracycline, and quinacrine were used for pleurodesis. In the 1980's tetracycline was the most commonly used agent primarily because a study in rabbits demonstrated that it was the most effective agent ${ }^{(7)}$. However, in the late 1980's the company that produced parenteral tetracycline terminated its production. Subsequently it was shown that doxycycline and minocycline were comparable in efficacy to tetracycline ${ }^{(8,9)}$.

When tetracycline became unavailable, the use of talc as a pleurodesis agent increased rapidly. Indeed, it is the agent most commonly used for pleurodesis at the present time $e^{(10)}$. Talc can be administered either as an aerosol (insufflation) or a suspension (slurry). Talc is the choice of many physicians because it is inexpensive, widely available and is perceived to be the most effective agent ${ }^{(11)}$. The primary problem with talc is that it has been incriminated in causing the acute respiratory distress syndrome (ARDS) which is fatal in approximately one percent of patients who receive it intrapleurally ${ }^{(12)}$. The mechanism for the ARDS is not definitely known, but it has been hypothesized that it is due to the systemic absorption of small talc particles ${ }^{(13)}$. Since the life expectancy of patients with malignancy is very limited, this would not necessarily mean that talc should not be used if it were significantly more effective than the other agents. Although it has been stated in the past that talc was 95\% effective and was much more effective than other agents ${ }^{(11)}$, this does not appear to be the case. In one analysis of 433 patients subjected to thoracentesis with talc, tetracycline derivatives or bleomycin, talc was no more effective than the other agents - all agents being approximately $80 \%$ effective ${ }^{(14)}$. In a recent study from Australia, the insufflation of talc at thoracoscopy in 66 malignant pleural effusions resulted in completed control in only $52 \%{ }^{(15)}$. Therefore, other agents should be considered.

There are two other agents that are inexpensive and widely available that may prove to be excellent agents for pleurodesis - silver nitrate and iodopovidone. Vargas and coworkers $^{(16,17)}$ have shown that silver nitrate is at least as good as the tetracycline derivatives or talc in producing pleurodesis in rabbits. Moreover, they have shown that $20 \mathrm{ml}$ of $0.5 \%$ silver nitrate produced control of 22 of 23 patients (95\%) with malignant effusions ${ }^{(18)}$. A recent article from Mexico reported that the intrapleural instillation of $20 \mathrm{ml} \mathrm{10 \%}$ iodopovidone plus $80 \mathrm{ml}$ normal saline resulted in complete control of the effusion 
in 50 of 52 patients (96\%) (19). In this study the iodopovidone was administered either through a chest tube or at the time of thoracostomy. Three patients did experience intense pleuritic pain and systemic hypotension after the instillation of the sclerosing agent, but they recovered without incident $^{(19)}$

In view of the above, what agent should be used for pleurodesis in 2003? I prefer not to use talc because of the possibility that its intrapleural instillation can induce ARDS and the fact that it is no more effective than other agents. My agent of choice is doxycycline $500 \mathrm{mg}$. Acceptable alternatives are

\section{References}

1. Light RW, Vargas FS: Pleural sclerosis for the treatment of pneumothorax and pleural effusion. Lung 1997; 175:213-23.

2. Light RW: Pleural Diseases. Fourth Edition. Lippincott, Williams and Wilkins, Baltimore, 2001.

3. Kinsey DL, Carter D, Klassen KP: Simplified management of malignant pleural effusion. Arch Surg 1964; 89:389-91.

4. Vargas FS, Wang N-S, Lee HM, Gruer SE, Sassoon $\mathrm{CSH}$, Light RW: Effectiveness of bleomycin in comparison to tetracycline as pleural sclerosing agent in rabbits. Chest 1993; 104:1582-4.

5. Vargas FS, Teixeira LR, Antonangelo L, Silva LMMF, Strunz CMC, Light RW: Acute and chronic pleural changes after the intrapleural instillation of mitoxantrone in rabbits. Lung 1998; 176:227-36.

6. Marchi E, Vargas FS, Teixeira LR, Fagundes DJ, Silva LMMF, Carmo AO, Light RW: Comparison of nitrogen mustard, cytarabine and dacarbazine as pleural sclerosing agents in rabbits. Eur Respir J 1997; 10:598-602.

7. Sahn SA, Good JT: The effect of common sclerosing agents on the rabbit pleural space. Am Rev Respir Dis $1981 ; 124: 65-7$.

8. Wu W, Teixeira LR, Light RW: Doxycycline pleurodesis in rabbits. Comparison of results with and without chest tube. Chest 1998; 114:563-8.

9. Light RW, Wang NS, Sassoon SCH, Gruer SE, Vargas FS: Comparison of the effectiveness of tetracycline and minocycline as pleural sclerosing agents in rabbits. Chest 1994; 106:577-82.

10. Lee YCG, Baumann MH, Eaton TE, Yasay JR, Waterer GW, Davies RJO, Heffner JE, Light RW: International survey of pleurodsis practice. Am J Respir Crit Care Medicine 2002; 165; A609.

11. Walker-Renard PB, Vaughan LM, Sahn SA: silver nitrate and iodopovidone. If I wanted to use an antineoplastic, I would use nitrogen mustard at a dose of $0.8 \mathrm{mg} / \mathrm{kg}$.

Richard W. Light, M.D.

Director, Pulmonary Disease Program Saint Thomas Hospital and Professor of Medicine Vanderbilt University, Nashville, TN Reprint Requests to:

Director of Pulmonary Disease Program Saint Thomas Hospital 4220 Harding Road

Nashville, Tennessee 37205

Phone: (615) 222-3043, Fax (615) 222-6564

E-Mail RLIGHT98@yahoo.com

Chemical pleurodesis for malignant pleural effusions. Ann Intern Med 1994; 120:56-64.

12. Light RW: Talc should not be used for pleurodesis. Am J Respir Crit Care Med 2000; 162:2023-6.

13. Ferrer J, Villarino MA, Tura JM, Traveria A, Light RW: Talc preparations used for pleurodesis vary markedly from one preparation to another. Chest 2001; 119:1901-5.

14. Heffner JE, Nietert PJ, Barbieri C. Pleural Fluid pH as a Predictor of Pleurodesis Failure. Chest 2000;117:79-86.

15. Love D, White D, Kiroff G. Thoracoscopic talc pleurodesis for malignant pleural effusion. ANZ J Surg 2003;73:19-22.

16. Vargas FS, Teixeira LR, Silva LMMF, Carmo AO, Light RW: Comparison of silver nitrate and tetracycline as pleural sclerosing agents in rabbits. Chest 1995; 108:1080-3.

17. Vargas FS, Teixeira LR, Vaz MAC, Carmo AO, Marchi E, Cury PM, Light RW: Silver nitrate is superior to talc slurry in producing pleurodesis in rabbits. Chest 2000; 118:808-13.

18. Vargas FS, Antonangelo L, Vaz MAC, Marchi E, Capelozzi VL, Genofre et al. Pleurodese induzida pela injeção intrepleural de nitrato de prata ou talco em colehos: há perspectivas para uso em humanos? J Pneumol 2003;29:57-63.

19. Vargas FS, Carmo AO, Teixeira LR: A new look at old agents for pleurodesis. Nitrogen mustard, sodium hydroxide and silver nitrate. Curr Opin Pulm Med 2000;6:281-6.

20. Olivares-Torres CA, Laniado-Laborin R, ChavezGarcia C, Leon-Gastelum C, Reyes-Escamilla A, Light RW: Iodopovidone pleurodesis for recurrent pleural effusion. Chest 2002; 122:581-3. 